\title{
Modulation of Oral Tolerance to Ovalbumin by Dietary Protein in Mice
}

\author{
Alizadeh MOHAMмAD ${ }^{1}$, Fusao OTA ${ }^{1, *}$, Afework KASsU ${ }^{1}$, \\ Kheirvari SORAYYA ${ }^{2}$ and Tohru SAKAI ${ }^{2}$ \\ ${ }^{1}$ Department of Preventive Environment and Nutrition, and \\ ${ }^{2}$ Department of International Public Health Nutrition, Institute of Health Biosciences, Graduate Schools, \\ The University of Tokushima, Tokushima 770-8503, Japan
}

(Received August 12, 2005)

\begin{abstract}
Summary This study sought to determine whether oral tolerance to ovalbumin (OVA), responsible for food allergy, is affected by different amounts of protein intake. For this, 6-wkold BALB/c mice were fed with low protein (5\%, LP), normal protein $(20 \%, \mathrm{NP})$ and high protein $(40 \%$, HP) diets, orally given either OVA (OVA-fed) or water (Water-fed) for $4 \mathrm{~d}$, and then immunized intraperitoneally twice at a 3-wk interval with alum-precipitated OVA. After the last immunization, sera were collected to measure total and OVA-specific IgE by enzyme assay (ELISA). Splenocytes were cultured and stimulated with concanavalin A (Con A), lipopolysaccharide (LPS) or OVA and assayed for ${ }^{3} \mathrm{H}$-thymidine incorporation. The culture supernatants from their splenocytes stimulated with OVA were analyzed for interleukin (IL)-4, interferon (IFN)- $\gamma$, and IL-12. Total IgE was significantly higher in OVA-fed HP groups as compared to NP and LP groups $(p<0.05)$. The highest and the lowest OVA-specific IgE were observed in HP and LP diet groups, respectively $(p<0.05)$. OVA-fed mice receiving the LP diet demonstrated significantly lower IL-4 as compared to the other two groups $(p<0.05)$, while IFN- $\gamma$ was significantly higher in the LP compared to the HP group $(p<0.05)$. Levels of IL-12 did not differ among the OVA-fed groups. Splenocytes of OVA-fed mice kept on the LP and HP diet showed significant impairment of proliferation to OVA as compared to the NP group $(p<0.01)$. Proliferation against Con A was impaired in the LP group compared to the NP group $(p<0.05)$ but not in Water-fed groups. However, it was higher against LPS in the HP than the LP group $(p<0.05)$ both in Water-fed and OVA-fed animals. All these findings indicate that established oral tolerance to OVA is clearly affected by the amount of protein diet. They support the suggestion that dietary protein plays an important role(s) in IgE-mediated food allergies.
\end{abstract}

Key Words oral tolerance, protein diet, food allergy, IgE, IL-4

Oral tolerance is defined as an inhibition of specific immune responsiveness to subsequent parenteral injection of a protein to which an individual or animal has been previously exposed via the oral route. This has been considered as a possible therapeutic approach to manage adverse immune functions such as autoimmune diseases and allergies including food allergies (14). In fact, the gastrointestinal mucosa are equipped as a physiologic pathway of systemic immune tolerance against dietary food antigens to prevent undesirable immune responses $(5,6)$.

Immune response can be suppressed by a single or multiple antigen feeds to inhibit subsequent IgM, IgG and IgE antibody response, and cell-mediated immune (CMI) response as well (5). Although antibody responses to soluble antigens are generally more difficult to suppress than CMI, IgE response seems to deviate from this rule, being remarkably susceptible to induction of oral tolerance. Nevertheless, it is interest-

*To whom correspondence should be addressed.

E-mail: ota@nutr.med.tokushima-u.ac.jp ing to note that all these immune responses are frequently implicated in human food hypersensitivity diseases.

Immune regulation by the induction of oral tolerance to food antigens is thought to prevent food allergy (7). Food allergy and food intolerance seem to be more frequent than ever. In adults, food intolerance occurs in around $1-2 \%$ of the population and only a small proportion of this number is truly allergic to food $(8)$. In children, the incidence of food intolerance is estimated at $5-7 \%$, while the prevalence of IgE-mediated food allergy is reported to be about $1-2 \%(8)$. Food allergy indicates an increasing tendency even in a developing country (9). Meanwhile, nutritional status appears to be one of the influential factors for increased allergic reactions, judging from the rarity of allergic diseases before World War II and their frequent consideration as a social problem caused by changes of life and dietary habits in the past few decades $(10,11)$.

Protein-energy malnutrition is a serious health problem in developing countries where the prevalence of allergies is lower than in developed countries (12-14). 
Both insufficient and excess protein feeding may exert adverse food effects. There are only a few reports focusing on the effect of nutritional status on oral tolerance to food antigens (14). We have previously reported the effect of protein restriction on oral tolerance $(15,16)$. Although there is a report on the effect of moderate $(10 \%)$ and high $(40 \%)$ protein diets on IgE response in animals without induction of tolerance (17), there are no reports addressing the effect of high dietary protein on the induction of oral tolerance. The objective of this study was, therefore, to peruse the effects of low and high dietary protein intake on an established oral tolerance to ovalbumin (OVA), a food antigen, and to compare them with those fed with a normal diet as a control.

\section{MATERIALS AND METHODS}

Animals, diets and husbandry. Specific pathogen free $\mathrm{BALB} / \mathrm{c}$ mice at $6 \mathrm{wk}$ of age, weighing 15-20 g were purchased (Japan SLC, Inc., Shizuoka, Japan) and fed on an ordinary commercial diet (Oriental Yeast Co. Ltd., Tokyo, Japan) for $1 \mathrm{wk}$. They were randomly divided into three groups receiving a low protein ( $5 \%$, LP), normal protein $(20 \%$, NP), or high protein $(40 \%$, HP) diet. The mice in each group were further subdivided into tolerant (OVA-fed) and non-tolerant (Water-fed) groups. All the diets containing casein, as source for protein (\% of $w / w)$, were made into a dough with half of its weight in water. As shown in Table 1, the diets were adjusted to

Table 1. Composition of experimental diet.

\begin{tabular}{lrcr}
\hline & \multicolumn{3}{c}{ Dietary protein } \\
\cline { 2 - 4 } Constituent $(\mathrm{g} / \mathrm{kg})$ & $\begin{array}{c}\text { Low } \\
\text { protein }\end{array}$ & $\begin{array}{c}\text { Normal } \\
\text { protein }\end{array}$ & $\begin{array}{c}\text { High } \\
\text { protein }\end{array}$ \\
\hline Casein $_{\text {Carbohydrate }}$ & 50 & 200 & 400 \\
Cellulose $_{\text {Mineral mixture }}^{2}$ & 820 & 670 & 470 \\
Vitamin mixture $^{3}$ & 20 & 20 & 20 \\
Corn oil $_{\text {Total energy }(\mathrm{kcal} / \mathrm{kg})}$ & 50 & 50 & 50 \\
& $5,930^{4}$ & $3,930^{5}$ & $3,930^{6}$ \\
\hline
\end{tabular}

\footnotetext{
${ }^{1}$ Starch : sucrose, $2: 1$ ratio.

${ }^{2}$ The mixture consists of $\left(\mathrm{mg} / \mathrm{kg}\right.$ diet): $\mathrm{CaHPO}_{4} \cdot 2 \mathrm{H}_{2} \mathrm{O}$, 7,280; $\mathrm{KH}_{2} \mathrm{PO}_{4}, 12,860 ; \mathrm{NaH}_{2} \mathrm{PO}_{4}, 4,680 ; \mathrm{NaCl}, 2,330$; Ca-lactate, 17,550; Fe-citrate, 1,590; $\mathrm{MgSO}_{4}, 3,590$; $\mathrm{ZnCO}_{3}, 55 ; \mathrm{MnSO}_{4} \cdot 4-6 \mathrm{H}_{2} \mathrm{O}, 60 ; \mathrm{CuSO}_{4} \cdot 5 \mathrm{H}_{2} \mathrm{O}, 15 ; \mathrm{KI}, 5$. ${ }^{3}$ The composition is expressed in units or milligrams of vitamins per $\mathrm{kg}$ of diet: thiamine- $\mathrm{HCl}, 12$; riboflavin, 40; pyridoxine- $\mathrm{HCl}$, 8; vitamin $\mathrm{B}_{12}, 0.005$; ascorbic acid, 300; D-biotin, 0.2; folic acid, 2; calcium pantothenate, 50; $p$-aminobenzoic acid, 50; niacin, 60; inositol, 60; choline chloride, 2,000; retinol acetate, 5,000; ergocalciferol, 1,000 IU; tocopherol acetate, 50; menadione, 52. ${ }^{4}$ Total energy obtained from protein, carbohydrate and lipid was $39.37,38.14$ and $22.15 \%$, respectively.

${ }^{5}$ Total energy obtained from protein, carbohydrate and lipid was $19.68,58.17$ and $22.15 \%$, respectively.

${ }^{6}$ Total energy obtained from protein, carbohydrate and lipid was $4.92,72.93$ and $22.15 \%$, respectively.
}

be isocaloric despite their various amounts of protein content. The mice were housed in a room maintained at $22 \pm 2^{\circ} \mathrm{C}$ on a $12 \mathrm{~h}$ light/dark cycle from 8.00 a.m. to 8.00 p.m. and were allowed free access to the experimental diet. Every 2nd day, at a set time, food intake and body weight of mice were measured, and food and water renewed. This study was approved by the Animal Research Ethics Committee at The University of Tokushima, Japan.

Induction of oral tolerance and immunization. At $3 \mathrm{wk}$ after starting the experimental diet, some mice were given orally for four consecutive days $5 \mathrm{mg}$ of OVA ( $5 \times$ crystallized, Seikagaku Corp., Tokyo, Japan) dissolved in $0.5 \mathrm{~mL}$ of sterile distilled water by means of a plastic gavage needle. The other animals, belonging to the Water-fed subgroup of each dietary group, were treated in the same manner except for OVA. Four days after the last feeding, mice were immunized twice at a 3-wk interval with $100 \mu \mathrm{g}$ of alum-precipitated OVA dissolved in phosphate-buffered saline (PBS).

Preparation of blood serum. Mice were anesthetized with diethyl ether in a jar. Blood was collected from inferior vena cava and sera were prepared after centrifugation and kept at $-70^{\circ} \mathrm{C}$ until used.

Measurement of total IgE in serum. Total IgE was examined by an ELISA method as previously described (15). Briefly microtiter plates (Greiner Labortechnik, Gmbh) were coated with rat antimouse IgE monoclonal antibody (Yamasa Corporation, Chiba, Japan) diluted in carbonate buffer (50 mM, pH 9.6) and then incubated overnight at $4^{\circ} \mathrm{C}$. To block non-specific binding sites, the wells were treated at room temperature with $300 \mu \mathrm{L}$ of $3 \%(\mathrm{w} / \mathrm{v})$ BSA dissolved in Tris-HCl buffer $(25 \mathrm{~mm}$, $\mathrm{pH} 7.4$ ) containing $0.14 \mathrm{M} \mathrm{NaCl}, 5 \mathrm{~mm} \mathrm{KCl}$. The plates were washed four times with PBS containing 0.05\% Tween 20 (PBS-T). Then, ten-fold diluted serum samples and serially diluted antidinitrophenyl monoclonal mouse IgE were added to the wells for further incubation at $4^{\circ} \mathrm{C}$ for $2 \mathrm{~h}$. The plates were washed four times with the washing buffer before addition of $100 \mu \mathrm{L}$ of 1 / 1,000 diluted biotinylated rat monoclonal anti-mouse IgE antibody (Yamasa Corporation) and incubated for $1 \mathrm{~h}$ at $4^{\circ} \mathrm{C}$. They were washed five times with the buffer and then reacted with avidin-HRP at room temperature for $1 \mathrm{~h}$. The plates were again washed seven times, and then color development was performed after addition of TMBZ solution as a substrate. The reaction was stopped using $1 \mathrm{M} \mathrm{H}_{3} \mathrm{PO}_{4}$ and results were read at $450 \mathrm{~nm}$ using an ELISA reader (Bio-Rad Laboratories, Inc., USA).

Measurement of OVA specific IgE in serum. IgE antibody levels against OVA were determined by an indirect ELISA method as described previously (15). Briefly, OVA was dissolved at a concentration of $100 \mu \mathrm{g} / \mathrm{mL}$ in 50 mM carbonate buffer, $\mathrm{pH} 9.6$, and $100 \mu \mathrm{L}$ of this was applied to each well of plates (Greiner Labortechnik, Gmbh). The microplate wells were incubated first for $30 \mathrm{~min}$ at room temperature with shaking and subsequently overnight at $4^{\circ} \mathrm{C}$. To block the remaining binding sites on the well surface, the wells were treated at room temperature for $2 \mathrm{~h}$ with $300 \mu \mathrm{L}$ of $3 \%(\mathrm{w} / \mathrm{v}) \mathrm{BSA}$ 
dissolved in Tris-HCl buffer ( $25 \mathrm{~mm}, \mathrm{pH} 7.4$ ) containing $0.14 \mathrm{M} \mathrm{NaCl}, 5 \mathrm{mM} \mathrm{KCl}$. They were washed four times with PBS-T, added with $100 \mu \mathrm{L}$ of test sera diluted 10 , 50 , and 100 fold in buffer containing $20 \mathrm{~mm}$ Tris- $\mathrm{HCl}$, $\mathrm{pH}$ 7.2, PMSF and $10^{-5} \mathrm{M}$ leopeptin, and incubated for $2 \mathrm{~h}$. They were washed again in a similar way before addition of $100 \mu \mathrm{L}$ of biotinylated rat anti-mouse IgE monoclonal antibodies (Yamasa Corporation) diluted 1:1,000. After incubation for $90 \mathrm{~min}$ at room temperature, the wells were washed and treated with $100 \mu \mathrm{L}$ of avidin-HRP for $1 \mathrm{~h}$. The wells were finally washed seven times and supplemented with $100 \mu \mathrm{L}$ of a solution of TMBZ as the substrate of HRP, and the color was allowed to develop for $30 \mathrm{~min}$ at room temperature. The reaction was stopped by adding $50 \mu \mathrm{L}$ of $1.0 \mathrm{M} \mathrm{H}_{2} \mathrm{SO}_{4}$, and absorbance (OD) was read at $450 \mathrm{~nm}$ using the microplate reader.

Cytokine production. Spleens were removed 1 wk after the second i.p. immunization with alum-precipitated OVA. After being anesthetized, mice were killed and cell suspensions were prepared as described by Zhang and Petro (18) with some modifications. Briefly, spleens were aseptically removed and positioned in a sterile petri dish with $15 \mathrm{~mL}$ of RPMI-1640 (Sigma) medium containing antibiotic-antimycotic (GIBCO BRL Life) at room temperature. Spleens were minced with a sterile syringe in a dish containing culture medium and the resulting suspension was then transferred to a sterile centrifuge tube. Erythrocytes in the spleen cell suspensions were lyzed by incubation in $0.83 \% \mathrm{NH}_{4} \mathrm{Cl}$ in Tris-HCl ( $\mathrm{pH} 7.4)$.

Aliquots $\left(5 \times 10^{6}\right.$ cells/well) of the spleen cell suspensions in RPMI-1640 medium containing antibioticantimycotic, $25 \mathrm{~mm}$ HEPES, $5 \times 10^{-5} \mathrm{M}$ 2-mercaptoethanol, $10 \%$ heat inactivated fetal bovine serum were dispensed into 24-well culture plates. They were then stimulated with $100 \mu \mathrm{g} / \mathrm{mL}$ of $\mathrm{OVA}$ at $37^{\circ} \mathrm{C}$ in a $\mathrm{CO}_{2}$ incubator under an atmosphere of $5 \% \mathrm{CO}_{2}$. After $72 \mathrm{~h}$ incubation, supernatants of three cultures from each mouse were collected by centrifugation at $400 \times g$ for $5 \mathrm{~min}$ and were combined for analysis of interleukin (IL)-4, interferon (IFN)- $\gamma$, and IL-12 by ELISA.

Cytokine measurements in culture supernatants. The levels of IL-4, IFN- $\gamma$ and IL-12 in the culture supernatants of splenocytes were measured following the conventional method. Briefly, 96-well microtiter plates (Nunc Maxisorp) were coated with $100 \mu \mathrm{L} /$ well of antimouse IL-4, IFN- $\gamma$ and IL-12 monoclonal antibody (eBioscience, USA) and incubated overnight at $4^{\circ} \mathrm{C}$. The immunoplate wells were washed four times with PBS-T. Nonspecific binding sites were blocked by treatment with $200 \mu \mathrm{L}$ of special buffer following the manufacturer's instruction. After three washings with PBS-T, they were then incubated for $90 \mathrm{~min}$ at $4^{\circ} \mathrm{C}$ with samples of culture supernatants. For standard curves, the plates were incubated in the same way with serial dilutions following manufacturer's recommendations. The wells were washed five times with PBS-T and then incubated at room temperature for $1.5 \mathrm{~h}$ with biotinylated antimouse IL-4, IFN- $\gamma$ and monoclonal IL-12 antibody.
The plates were washed and incubated for $30 \mathrm{~min}$ with avidin-HRP. Finally, after seven washings with the washing buffer, a TMBZ substrate was added and the reaction was stopped. The results were read at $450 \mathrm{~nm}$ using the ELISA reader.

Lymphocyte proliferation assay. Spleens were removed 1 wk after the second i.p. immunization. After being anesthetized, mice were sacrificed and cell suspensions were prepared as described above. Cells were washed three times with RPMI-1640 medium and then re-suspended to provide $2.5 \times 10^{6}$ cells $/ \mathrm{mL}$ in RPMI-1640 medium containing antibiotic-antimycotic, $25 \mathrm{~mm}$ HEPES, $5 \times 10^{-5} \mathrm{M} 2$-mercaptoethanol and $10 \%$ heat inactivated fetal bovine serum (Flow Laboratories Inc, McLean, VA, USA). Cells $\left(5 \times 10^{5}\right.$ cells/well) were cultured in triplicate wells for $96 \mathrm{~h}$ in the medium with $5 \mu \mathrm{g} / \mathrm{mL}$ of concanavalin A (Con A), $10 \mu \mathrm{g} / \mathrm{mL}$ lipopolysaccharide (LPS) or $100 \mu \mathrm{g} / \mathrm{mL}$ OVA, and incubated at $37^{\circ} \mathrm{C}$ in a humidified atmosphere of $5 \% \mathrm{CO}_{2}$. For the last $17 \mathrm{~h}$ of the culture period, the cells were exposed to $2 \mu \mathrm{Ci}\left[{ }^{3} \mathrm{H}\right.$ ] thymidine (specific activity: $74 \mathrm{GBq} /$ mmol, Amersham Pharmacia Biotech, England). The cells were harvested using a filter glass and counted for radioactivity with a direct beta counter (MATRIX ${ }^{\mathrm{TM}}$ 9600, PACKARD, A Canberra Company, USA).

Statistical analysis. Data were reported as mean \pm SD. Statistical analysis was performed with the Statistical Package for Social Sciences (SPSS 10.0, Chicago, IL, USA). For multiple comparisons among different dietary groups, the data were first analyzed by one-way analysis of variance (ANOVA) and then by the TukeyKramer test. A Student's t-test or Mann-Whitney U-test was used to evaluate the effect of OVA feeding within a dietary group where appropriate. $p$ values less than 0.05 were considered significant.

\section{RESULTS}

\section{Food intake and body weight}

Food intake and body weight of mice were affected by dietary protein content. As shown in Table 2, mice receiving the LP diet showed significantly higher food intake as compared to the NP and HP diet $(p<0.001)$. Analysis of the initial and final body weight showed an average gain of $1.42 \pm 0.54 \mathrm{~g}$ in the HP group when compared to $0.77 \pm 0.076 \mathrm{~g}$ observed in the control $(p<0.001)$. Mice fed with the LP diet failed to gain weight and they started to lose weight after the second immunization with OVA.

Total and OVA-specific IgE in serum

To determine whether oral tolerance to OVA could be modulated by the amount of protein intake, sera of mice maintained on three protein diets were collected $1 \mathrm{wk}$ after the second immunization and analyzed for total and OVA-specific IgE. As shown in Fig. 1A, oral feeding with OVA resulted in statistically significant suppression of total IgE in all dietary groups as compared to the corresponding Water-fed groups $(p<0.01)$. When Waterfed experimental mice were compared, the levels of total IgE did not show any difference. But, OVA-fed animals maintained on the HP diet displayed a higher titer of 
Table 2. Body weight and food consumption. ${ }^{1}$

\begin{tabular}{lccc}
\hline & \multicolumn{3}{c}{ Dietary group } \\
\cline { 2 - 4 } & Low protein $(5 \%, n=8)$ & Normal protein $(20 \%, n=8)$ & High protein $(40 \%, n=6)$ \\
\hline Initial body weight $(\mathrm{g})$ & $19.00 \pm 0.98$ & $19.01 \pm 1.09$ & $18.71 \pm 0.98$ \\
Final body weight $(\mathrm{g})$ & $16.69 \pm 1.77^{*}$ & $19.78 \pm 1.85$ & $20.13 \pm 1.53^{*}$ \\
Body weight gain $(\mathrm{g} / 8 \mathrm{wk})$ & $-2.16 \pm 0.78$ & $0.77 \pm 0.76$ & $1.42 \pm 0.54$ \\
Food intake $(\mathrm{g} / \mathrm{d})$ & $4.12 \pm 0.63^{*}$ & $3.54 \pm 0.62$ & $3.30 \pm 0.65^{*}$ \\
\hline
\end{tabular}

\footnotetext{
${ }^{1}$ Data are mean \pm SD. Asterisks represent $p$ values less than 0.001 versus control.
}
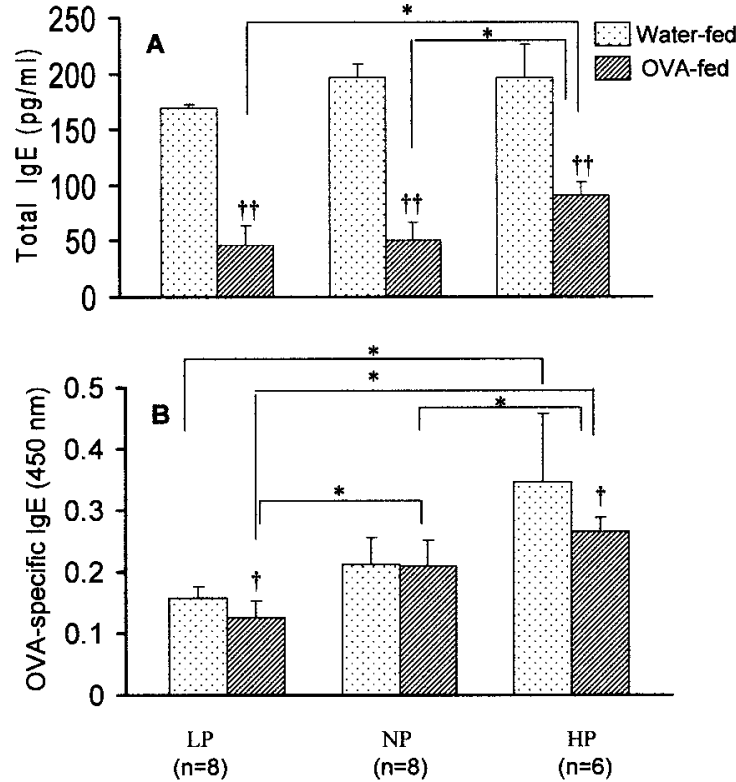

Fig. 1. Total and OVA-specific IgE production in 10-fold diluted serum samples of mice fed with low, normal and high protein diet. Mice were pretreated orally with $5 \mathrm{mg} / \mathrm{d}$ of either OVA or water for $4 \mathrm{~d}$. They were then immunized with $100 \mu \mathrm{g} /$ mouse of alum-precipitated OVA twice at a 3-wk interval. One week later, sera were prepared and total (A) and OVA-specific (B) IgE titers were measured using ELISA as described in "Materials and Methods." The results are expressed as mean \pm SD calculated from data taken from 6-8 mice. Dotted and crossed columns represent Water-fed and OVA-fed mice, respectively. LP, NP, and HP represent mice fed with low (5\%) protein, normal $(20 \%)$ protein, and high $(40 \%)$ protein. Single asterisks represent $p$ values less than 0.05 . Single and double daggers indicate $p$ values less than 0.05 and 0.01 , respectively, versus Water-fed group.

total IgE compared to the NP and LP groups $(p<0.05)$. As shown in Fig. 1B, OVA-specific IgE was suppressed by OVA feeding in animals kept in the LP and HP $(p<0.05)$ but not in the NP group. However, it should be mentioned that significant suppression of OVA-specific IgE in all OVA-fed groups was observed when several dilutions of serum samples were assayed for the antibody (data not shown). Tolerant mice showed proportional increases in OVA-specific IgE antibody titers with increasing protein in the diet. OVA feeding resulted in significantly higher titers of OVA-specific IgE in HP fed mice compared to both the NP and HP groups $(p<0.05)$. OVA-specific IgE was also significantly lower in the LP-fed tolerant animals as compared to those fed with the NP diet $(p<0.05)$. Among the Water-fed groups, titers of OVA-specific IgE were found to be significantly higher in the HP than those in the LP group $(p<0.05)$. Cytokine production from splenocytes

Among many cytokines, IL- 4 and IFN- $\gamma$ have potent effects on B cells switching to IgE antibody production. Thus, we assessed the production of these two cytokines from splenocytes after stimulation with OVA. As shown in Fig. 2A, a lower production of IL-4 was detected in OVA-fed mice receiving the LP diet as compared to those of the NP $(p<0.05)$ and HP $(p<0.05)$ groups. Water-fed mice kept on the HP diet displayed a higher production of IL-4 as compared to those in the LP and NP dietary groups but the difference was significant only with the former $(p<0.05)$. In contrast, as shown in Fig. 2B, OVAfed mice showed higher titers of IFN- $\gamma$ in the LP group compared to the HP group $(p<0.05)$. OVA-fed mice receiving the NP diet had an intermediate level of IFN- $\gamma$ among the three groups, although the difference was not significant. Water-fed mice receiving the NP diet had higher titers of IFN- $\gamma$ as compared to both LP and HP groups $(p<0.05)$.

IL-12 is an important cytokine involved in the regulation of cell-mediated immunity and induction of Th1 differentiation (19). Its signaling is also essential for induction of optimal levels of IFN- $\gamma$. In an attempt to investigate the possible role of IL-12 in IgE tolerance in association with dietary protein, we next examined the cytokine in the culture supernatants when splenocytes were stimulated with OVA using ELISA. As shown in Fig. 2C, feeding with a HP diet resulted in higher production of IL-12 as compared to the NP group $(p<0.05)$ in Water-fed mice. But, no remarkable change in the production of the cytokine was observed by OVA feeding in any of the experimental groups.

Lymphocyte proliferation assay

To determine the effect of dietary protein, with or without an induced tolerance, on $\mathrm{T}$ cell-specific responses, we stimulated splenocytes of mice taken from the LP, NP, and HP diet groups with OVA and assayed for ${ }^{3} \mathrm{H}$-thymidine incorporation. As shown in Fig. 3A, OVA feeding resulted in a lower proliferation against 

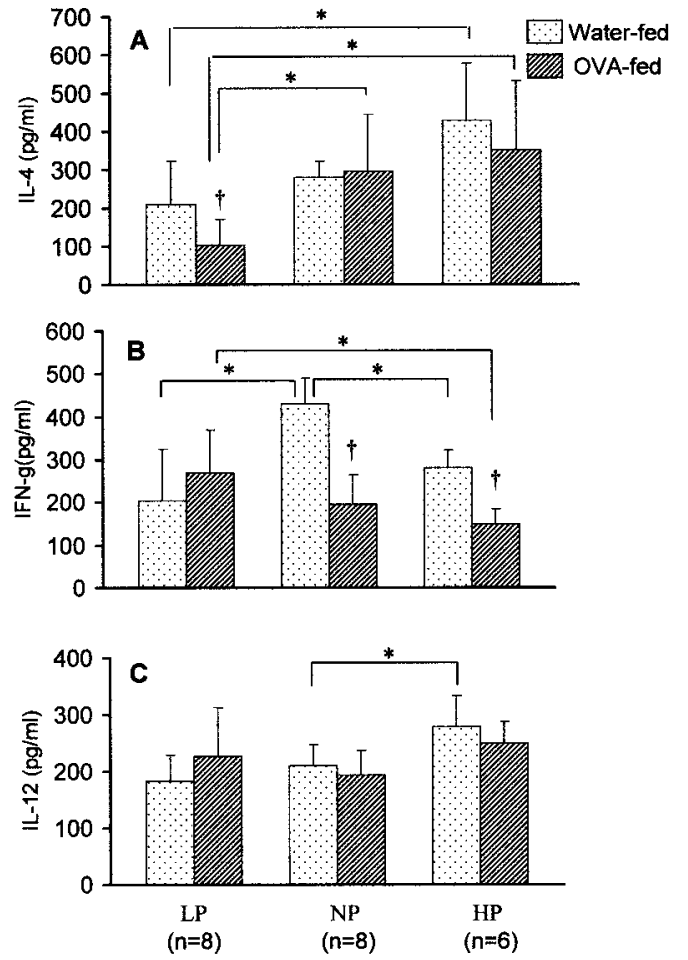

Fig. 2. Effect of OVA stimulation on cytokine production from splenocytes. Aliquots of $5 \times 10^{6}$ splenocytes were dispensed in triplicate wells and stimulated with $400 \mu \mathrm{g} / \mathrm{mL}$ of OVA in medium. After $72 \mathrm{~h}$ incubation, culture supernatants were collected and used for determination of IL-4 (A), IFN- $\gamma$ (B), and IL-12 (C) as described in "Materials and Methods." The results are shown as means \pm SD calculated from data taken from 6-8 mice. Dotted and crossed columns represent Water-fed and OVA-fed mice, respectively. LP, NP, and HP represent mice fed with low $(5 \%)$ protein, normal $(20 \%)$ protein, and high $(40 \%)$ protein. Single asterisks represent $p$ values less than 0.05 . Daggers indicate $p$ values less than 0.05 versus Water-fed group.

OVA as compared to the corresponding Water-fed groups. The difference in the proliferation was statistically significant within the LP, NP and HP groups $(p<0.05)$. The tolerant animals maintained on either the LP or HP diet also showed substantially lower proliferation as compared to NP $(p<0.01)$. There was no remarkable change in proliferative response to OVA by splenocytes among the Water-fed groups.

Stimulation of splenocytes with Con A and LPS was performed to investigate the effect of dietary protein status on lymphocyte proliferation in both OVA-fed and Water-fed groups. As shown in Fig. 3B, regardless of the amount of dietary protein, induction of tolerance was associated with significant impairment in proliferation as compared to the corresponding Water-fed groups $(p<0.05)$. Besides, OVA-fed mice maintained on the LP diet showed a significantly lower proliferation in response to Con A as compared to the NP animal group $(p<0.05)$. The proliferative response did not show a remarkable difference in animals fed with the HP diet in comparison to the two other groups.

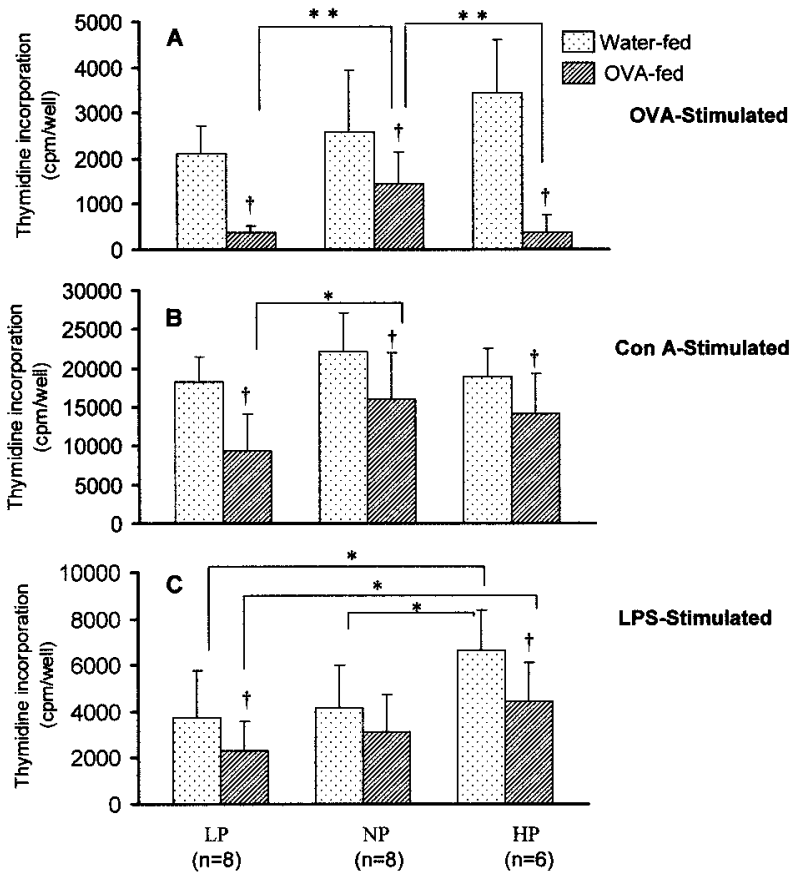

Fig. 3. Proliferative response of splenocytes to OVA, Con A and LPS. Spleen cell suspensions $\left(2.5 \times 10^{6}\right)$ were prepared as described in "Materials and Methods." They were incubated in triplicate wells and cultured for $96 \mathrm{~h}$ with medium, $100 \mu \mathrm{g} / \mathrm{mL}$ OVA (A), $5 \mu \mathrm{g} / \mathrm{mL}$ of Con A (B), and $10 \mu \mathrm{g} / \mathrm{mL}$ LPS (C) by incubation at $37^{\circ} \mathrm{C}$ in a humidified atmosphere of $5 \% \mathrm{CO}_{2}$. For the last $17 \mathrm{~h}$ of culture period, the cells were exposed to $2 \mu \mathrm{Ci}\left[{ }^{3} \mathrm{H}\right]$ thymidine. Data were calculated after subtracting readings for control (media only) and expressed as mean \pm SD calculated from data taken from 6-8 mice. Dotted and crossed columns represent Water-fed and OVA-fed mice, respectively. LP, NP, and HP represent mice fed with low $(5 \%)$ protein, normal $(20 \%)$ protein, and high $(40 \%)$ protein diet. Single and double asterisks represent $p$ values less than 0.05 and 0.01, respectively. Single daggers indicate $p$ values less than 0.05 versus Water-fed group.

When tested to LPS, both in tolerant and non-tolerant animals, lymphocyte proliferation tended to show a proportional increase to the increasing amount of protein in the diet (Fig. 3C). Both OVA-fed and Water-fed mice receiving the HP diet showed a significantly higher proliferation as compared to LP animals $(p<0.05)$. Finally, when the proliferation to LPS among the Waterfed animals was compared, it was significantly lower in the NP group as compared to the HP group $(p<0.05)$.

\section{DISCUSSION}

It has been shown in animal models that specific immunological oral tolerance can be induced with proteins $(20,21)$. In addition, plenty of reports have shown that digested formulas can stimulate the gut immune system towards induction of tolerance in newborns with an elevated risk of allergies $(22,23)$. However, there have been only a few reports addressing the effect of nutritional status on oral tolerance $(15,24)$ and vir- 
tually no reports addressing the effect of high dietary protein on it.

Food intake was dependent on the level of dietary protein with the greatest food intake in the LP group and the lowest in the HP diet group. In diet selection experiments, it has been demonstrated that young animals were able to match their protein intake closely to their protein requirement and chose the appropriate energy from protein (25). Thus, it may be reasonable that mice fed the LP diet should eat more than those fed the NP and HP diet to increase their protein intake. However, regardless of the increase in food intake, the total protein intake in mice fed on the LP diet was still lower than that of the other groups. It was reported that, when dietary protein was severely limited, animals still had a higher percentage of body fat as compared to those fed a normal protein diet, in spite of the decrease in the amount of fat (25). Accordingly, body protein and body water should be affected to a greater degree than body fat by severe limitation of protein in the diet. Their expected decrease in body protein and body water also explains why body weights decreased with low dietary protein, despite the general increase in food intake and body fat. It also explains the weight gain observed with the high protein diet in the present study. This observation was also in a good agreement with the previous report (17).

A decrease in serum IgE response together with diminished T-cell responses is likely the hallmark of oral tolerance (26). Among allergic reactions, type I hypersensitivity (IgE mediated allergic reaction) is one of the most prevalent types of food allergies (10). It has been reported previously from our laboratory that mice fed with a low protein diet were more prone to the induction of oral tolerance to OVA (15). Using $\beta$-lactoglobulin, a major allergen in cow's milk, it was latter confirmed that this effect of protein on the induction of tolerance was not limited to OVA (16). Several factors affect the induction of oral tolerance to a dietary antigen. The dose and nature of antigen, and strain and age of animals are among the most influential ones. The protocol used for the induction of oral tolerance in the current study is identical with that used in previous publications from our laboratory showing antigen specificity for the immune responses including OVA-specific IgE antibody $(15,16)$. Judging from levels of OVA-specific IgE, mice fed with the NP diet were relatively resistant to induction of the oral tolerance to OVA which agrees with our previous report (15). Our results, also, indicate that higher levels of dietary protein modulate negatively an established oral tolerance by augmenting IgE levels which are normally induced after OVA feeding. It is likely that in animals fed with the LP diet down-regulation of Th2-dependent responses might have occurred after OVA feeding, while the reverse might hold true with the HP diet. Taken together, based on the observations it is speculated that antigen-primed animals on the diet with HP content are prone to greater IgE responses which likely predispose them to IgE mediated allergic disorders.
Regarding the regulatory mechanisms of IgE secretion, early studies have reported that elevated IL- 4 and reduced IFN- $\gamma$ production are associated with elevated serum IgE levels $(27,28)$. The cytokines, therefore, play an important role in tolerance mechanisms, especially those involving active cellular regulation (29). The Th1 cytokine, IFN- $\gamma$, is well documented for antagonistic effects on IL-4-mediated activities and, therefore, negatively regulates IgE production. Both cytokines greatly affect Th1 and Th2 lymphocyte functions (30). It has also been well documented that shifting the Th1/Th2 balance to Th2 dominance is associated with allergic diseases (31). In the present study, these two cytokines were significantly different in tolerant (OVA-fed) mice receiving varying amounts of dietary protein compared with non-tolerant (Water-fed) animals. Although OVA feeding had no remarkable effect on the production of IL-4 in animals fed with either the NP or HP diet, significant suppression of the cytokine was observed for protein restriction. On the other hand, while production of IFN- $\gamma$ was moderately augmented after induction of tolerance in mice fed with the LP diet, it was significantly suppressed in those fed with either the NP or LP diets. These suggest that regulatory cells might be generated during tolerance induction and indicate that the LP diet induces a higher IFN- $\gamma$, which in turn regulates Th2 functions downwards and subsequently results in a low IL-4. A low IL-4 may also directly induce a low IgE production. Nevertheless, the animals with excess intake of protein showed reduced production of IFN- $\gamma$ and IgE.

IL-12 is also known to be important in IgE production directing undifferentiated $\mathrm{T}$ cells towards $\mathrm{Th} 1$ polarization (32). Despite the observed modulation of IL- 4 and IFN- $\gamma$, production of IL- 12 was not affected by the amount of dietary protein in the present study except in Water-fed mice maintained on the HP diet as compared to the NP diet. It is worthy of note that the functional IL-12-dependent IFN- $\gamma$ signaling pathway does not play an important role in the induction of oral tolerance and IFN- $\gamma$ can be induced independently of IL-12 (33).

The pattern of lymphocyte proliferation in response to Con A and LPS seems to be due to both specific (16) and bystander suppression of lymphocyte activity by oral administration of the antigen. Despite the fact that proliferative response to OVA was not remarkably affected in non-tolerant (Water-fed) animals, it was significantly impaired in tolerant (OVA-fed) mice receiving both LP and HP diets. We speculated that the LP or HP diet might have contributed to suppression of a more profound Th2 or Th1 response, respectively. This hypothesis was further confirmed by our observation in the present study of a down-regulated Th1 and up-regulated Th2 immune response in animals fed with HP and LP diets, respectively. Therefore, the reduced OVAspecific proliferation in tolerant mice fed with the two diets is likely mediated by a defect in the development of a proper T-cell response. It is crucial to underline that OVA feeding resulted in general impairment of lymphocyte proliferation to both Con A and LPS. Yet, a rela- 
tively higher and lower proliferative response of the splenocytes to LPS and Con A in mice fed with HP as compared to NP groups may indicate a facilitator effect of the HP diet on the proliferation of B lymphocytes rather than $\mathrm{T}$ lymphocytes.

The HP and LP diets were set up to see an association with the overall protein intake in developed and developing countries, respectively, although the actual protein intake in both countries seems to range usually between the two extremes. Our findings on impeding and promoting effects of high and low protein diet on the induction of oral tolerance help to understand more the relation of IgE-mediated food allergies and dietary protein intake. Moreover, it should be considered that the low prevalence of allergic diseases in developing countries has been reported to be associated with the high prevalence of parasitic infections (13).

In summary, the effect of a high and low protein diet on established oral tolerance to OVA was examined. We observed that an established oral tolerance to OVA can be modulated by the amount of diet protein. In addition, the current study has also demonstrated, for the first time, that overintake of protein resulted in Th2 dominance in an established model of tolerance. The findings may also demonstrate that protein recommendations need to be re-evaluated from immunological points of view as well as their possible relation with lifestyle-related diseases. Further studies are warranted for detailed epidemiological investigation into differences among different populations with over- or underintake of protein in association with allergy and infection.

\section{Acknowledgments}

This work was supported in part by Grants-in-Aid (Nos. 11691211 and 14657017) from the Ministry of Education, Culture, Sports, Science and Technology of Japan, and also partly supported by a grant from Yakult Ltd., Japan. The authors also thank Dr. Aya Takeoka for her technical assistance and Dr. Masayuki Yamato for his valuable advice.

\section{REFERENCES}

1) Faria AM, Weiner HL. 1999. Oral tolerance: mechanisms and therapeutic applications. Adv Immunol 73: 153-264.

2) Wu HY, Weiner HL. 2004. Oral tolerance. Immunol Res 28: 265-284.

3) Mayer L, Shao L. 2004. Therapeutic potential of oral tolerance. Nat Rev Immunol 4: 407-419.

4) Strobel S. 1997. Oral tolerance: Immune response to food antigens. In: Food Allergy Adverse Reactions to Food Antigens and Food Additives (Metcalfe DD, Sampson HA, Simon RA, eds), p 107-135. Blackwell Science, Boston.

5) Fujihashi K, Kato H, van Ginkel FW, Koga T, Boyaka PN, Jackson RJ, Kato R, Hagiwara Y, Etani Y, Goma I, Fujihashi K, Kiyano H, McGhec JR. 2001. A revisit of mucosal IgA immunity and oral tolerance. Acta Odontol Scand 59: 301-308.

6) Strobel S, Mowat AM. 1998. Immune responses to dietary antigens: oral tolerance. Immunol Today 19:
173-181.

7) Mowat AM. 1987. The regulation of immune responses to dietary protein antigens. Immunol Today 8: 93-98.

8) Kagan RS. 2003. Food allergy: An overview. Environ Health Perspect 111: 223-225.

9) Chandra RK. 2003. Hypersensitivity and allergic diseases: A new threat in India. Indian Pediatr 40: 99-101.

10) Hijazi N, Abakhalil B, Seaton A. 2000. Diet and childhood asthma in a society in transition: a study in urban and rural Saudi Arabia. Thorax 55: 775-779.

11) Chandra RK. 2000. Food allergy and nutrition in early life: implications for later health. Proc Nutr Soc 59: 273-277.

12) Holen E, Elsayed S. 1999. Why does the prevalence of allergy increase more in industrialized than in developing countries? Tidsskr Nor Laegfroen 119: 3176-3177.

13) Yazdanbakhsh M, Kremsner PG, van Ree R. 2002. Allergy, parasites, and the hygiene hypothesis. Science 296: 490-494.

14) Helm RM, Burks AW. 2000. Mechanisms of food allergy. Curr Opin Immunol 12: 647-653.

15) Satter MA, Sakai K, Ahmed S, Yoshino K, Yamamoto S, Shimizu Y, Ota F. 2002. Low-protein diet induces oral tolerance to ovalbumin in mice. J Nutr Sci Vitaminol 48: 51-58.

16) Ahmed S, Satter MA, Yamamoto S, Maeda K, Minato Y, Ota F. 2003. Further evidence regarding the effect of dietary protein on oral tolerance against $\beta$-lactoglobulin through Th1-mediated immune response in mice. $J$ Nutr Sci Vitaminol 49: 112-119.

17) Yoshino K, Sakai K, Okada H, Sakai T, Yamamoto S. 2003. IgE responses in mice fed moderate protein deficient and high protein diets. J Nutr Sci Vitaminol 49:172-178.

18) Zhang S, Petro TM. 1997. The effect of moderate protein malnutrition on murine $\mathrm{T}$ cell cytotkine production. Nutr Res 17: 51-64.

19) Manetti RF, Gerosa MG, Giudizi R, Biagiotti R, Parronchi P, Piccnni MP, Sampognaro S, Maggi E, Romagnani S, Trinchieri G. 1994. Interleukin 12 induces stable priming for interferon $\gamma$ (IFN- $\gamma$ ) production during differentiation of human T helper (Th) cells and transient IFN- $\gamma$ production in established Th2 cell clones. J Exp Med 179: 1273-1283.

20) Thomas HC, Parrot DMV. 1974. The induction of tolerance to a soluble protein antigen by oral administration. Immunology 27: 631-639.

21) Hanson DG, Vaz NM, Maia L, Hombrook M, Lynch J, Roy C. 1977. Inhibition of specific immune responses by feeding protein antigens. Int Arch Allergy Appl Immunol 55: $526-532$.

22) Exl-Preysch BM, Fritsché R. 2004. Allergen reduced infant nutrition: Balancing the immune responses towards tolerance\& leading to better feeding tolerance\& less early allergic reactions. In: Nutrition and Immunology in 21st Centry (Chandra RK, ed), p 231-262. TSAR Health, Toronto, Canada, Gurgan, India.

23) Kjær TMR, Frøkiær H. 2002. Induction of oral tolerance with micro-doses of ovomucoid depends on the length of the feeding period. Scand J Immunol 55: $356-$ 365.

24) Lamont AG, Gordon M, Ferguson A. 1987. Oral tolerance in protein-deprived mice. Immunology 61: 333337.

25) Leathwood PD, Ashley DVM. 1983. Strategies of protein 
selection by weaning and adult rats. Appetite 4: 97112.

26) Chen Y, Inobe J, Marks R, Gonella P, Kuchroo VK, Weiner HL. 1997. Inductive events in oral tolerance in the TCR transgenic adoptive transfer model. Cell Immunol 178: 62-68.

27) Juio K, Renz H, Abe J, Gelfand EW, Leung DYM. 1992. Decreased interferon $\gamma$ and increased interleukin-4 production in atopic dermatitis promotes IgE synthesis. $J$ Allergy Clin Immunol 90: 323-331.

28) Rousset F, Robert J, Andray M, Bonnin JP, Souillet G, Chretien I, Briere F, Pene J, de Vries JE. 1991. Shifts in interleukin- 4 and interferon- $\gamma$ production by $\mathrm{T}$ cells of patients with elevated serum IgE levels and the modulatory effect of these lymphokines on spontaneous $\operatorname{IgE}$ synthesis. J Allergy Clin Immunol 87: 58-69.
29) Weiner HL. 2000. Oral tolerance, an active immunologic process mediated by multiple mechanisms. Clin Invest 106: 935-937.

30) Billiau A. 1996. Interferon- $\gamma$ : biology and role in pathogenesis. Adv Immunol 62: 61-130.

31) Abbas AK, Muphy KM, Sher A. 1996. Functional diversity of helper T lymphocytes. Nature 383: 787-793.

32) Piccotti JR, Chan SY, Li K, Eichwald EJ, Bishop DK. 1997. Differential effects of IL-12 receptor blockade with IL-12 p40 homodimer on the induction of $\mathrm{CD}^{+}$ and $\mathrm{CD}^{+}$IFN- $\gamma$-producing cells. J Immunol 158: 643648.

33) Mowat AM, Steel M, Andrew JL, Garside P. 1999. Normal induction of oral tolerance in the absence of a functional IL-12-dependent IFN- $\gamma$ signaling pathway. J Immunol 163: 4728-4736. 